The University of Southern Mississippi

The Aquila Digital Community

Faculty Publications

3-1-2004

\title{
Seasonal Use of Bridges by Rafinesque's Big-Eared Bat, Corynorhinus rafinesquii, in Southern Mississippi
}

\author{
Austin W. Trousdale \\ University of Southern Mississippi, austin.trousdale@usm.edu \\ David C. Beckett \\ University of Southern Mississippi, David.Beckett@usm.edu
}

Follow this and additional works at: https://aquila.usm.edu/fac_pubs

Part of the Biology Commons

\section{Recommended Citation}

Trousdale, A. W., Beckett, D. C. (2004). Seasonal Use of Bridges by Rafinesque's Big-Eared Bat, Corynorhinus rafinesquii, in Southern Mississippi. Southeastern Naturalist, 3(1), 103-112.

Available at: https://aquila.usm.edu/fac_pubs/16327

This Article is brought to you for free and open access by The Aquila Digital Community. It has been accepted for inclusion in Faculty Publications by an authorized administrator of The Aquila Digital Community. For more information, please contact Joshua.Cromwell@usm.edu. 


\title{
SEASONAL USE OF BRIDGES BY RAFINESQUE'S BIG-EARED BAT, CORYNORHINUS RAFINESQUII, IN SOUTHERN MISSISSIPPI
}

\author{
Austin W. Trousdale ${ }^{1, *}$ and David C. Beckett ${ }^{1}$
}

ABSTRACT - We conducted surveys of concrete bridges in southern Mississippi from 2000-2002 to determine the phenological pattern of use by Rafinesque's big-eared bat, Corynorhinus rafinesquii. The earliest dates on which we located maternity colonies were 9 March 2000, 20 April 2001, and 15 May 2002. Maternity colonies increased in size and abundance as spring progressed. Pups were born in mid- to late May (first observed 12 May 2000, 15 May 2001, 27 May 2002) and nursed through midsummer (lactating females last captured 14 July 2000, 25 July 2001, 16 July 2002). Colony size and percentage of bridges occupied by bats declined in late summer. Colonies were absent during fall and winter, although we occasionally found solitary individuals during these seasons. Number of bats present under an occupied bridge ranged from 1 to 25 . The mean number of individuals per occupied bridge was 4.6 (SD $=5.8)$ in $2000,3.9(\mathrm{SD}=5.0)$ in 2001 , and $3.0(\mathrm{SD}=4.4)$ in 2002. The mean number of adult females per maternity colony was $5.6(\mathrm{SD}=3.1)$. Although we found males throughout the study period, females were largely absent from bridges outside of the maternity season, suggesting that much of the population used alternate roosts during this time.

\section{INTRODUCTION}

Corynorhinus rafinesquii (Lesson), Rafinesque's big-eared bat, is an insectivorous bat native to the southeastern and south-central United States. The apparent rarity of $C$. rafinesquii led to its listing under the Endangered Species Act as a Category 2 species, meaning that it was possibly threatened or endangered when the designation was recognized, though conclusive information was lacking (Lance and Garrett 1997). At present, the species has been deemed a species of concern throughout its range (Harvey et al. 1999), and the vulnerability of its roosts to disturbance is hypothesized to have contributed to its apparent decline (Whitaker and Hamilton 1998). Corynorhinus rafinesquii seeks open, relatively well-lit conditions for roosts (Barbour and Davis 1969), using the twilight section of caves (Hurst and Lacki 1999), abandoned buildings (England et al. 1989, Jones and Suttkus 1975), cisterns (Hoffmeister and Goodpaster 1963), and cavities of large trees (Clark 1990).

\footnotetext{
'The University of Southern Mississippi, Department of Biological Sciences, 118 College Drive \#5018, Hattiesburg, MS 39406-5018. "Corresponding author - austin.trousdale@usm.edu.
} 
Lance and Garrett (1997) first reported that C. rafinesquii uses bridges as day-roosts. Furthermore, Lance and Garrett (1997) documented that maternity or nursery colonies occupied the undersides of concrete bridges in Louisiana. Lance et al. (2001) found that the percentage of mature deciduous forest surrounding a bridge was a significant factor in predicting occupancy by $C$. rafinesquii. Considering that the species of trees in which C. rafinesquii has been found to roost (e.g., Nyssa spp.: Clark 1990, Lance et al. 2001) are typical of such forests, $C$. rafinesquii may prefer bridges in close proximity to natural roosting sites. Use of bridges could also be a consequence of the species' tendency to switch roosts frequently (Lance et al. 2001, Trousdale and Beckett, unpubl.) with bridges serving as alternate roosts along with abandoned buildings (England et al. 1989, Jones and Suttkus 1975) and hollow trees (Lance et al. 2001). Concrete bridges may provide important shelter for $C$. rafinesquii, particularly in areas where natural roosts have been reduced or are scarce.

Bridges, particularly concrete ones, have long been recognized as providing shelter for a diversity of insectivorous bats. For example, Davis and Cockrum (1963) found that maternity colonies of Eptesicus fuscus, Tadarida brasiliensis, Antrozous pallidus, and Myotis spp. used bridges in Arizona. Adam and Hayes (2000) recorded E. fuscus, Corynorhinus townsendii, and several species of Myotis using bridges as night-roosts in Oregon. Potential advantages of bridges as roosts include their abundance in some areas, their relative permanence, and their capacity to house large numbers of individuals.

The objective of the present study was to describe the phenological progression of use of bridges by $C$. rafinesquii. Our results have applied implications, in addition to providing more information on the ecology of this species which is "one of the least known of all bats in the eastern United States" (Harvey et al. 1999). In a prior survey of the undersides of 99 bridges in central and southern Mississippi, we located six bridges in DeSoto National Forest (NF) that were used as daytime roosts by $C$. rafinesquii (Trousdale and Beckett 2002). Many of the bridges in DeSoto NF have since been slated for replacement due to decay of their wooden pilings. The U.S. Forest Service plans to retain the "cast-in-place" (Adam and Hayes 2000) style of construction used previously (D. Berens, pers. comm.) to facilitate use of these structures as roosts by $C$. rafinesquii (Lance et al. 2001). However, data on the duration and seasonal use of bridges by $C$, rafinesquii would also enable managers to better conserve this species. For example, the timing of events that relate to reproduction in this species (e.g., formation and duration of maternity colonies) should influence decisions regarding removal and subsequent replacement of concrete bridges. 


\section{STUDY AREA}

The present study was conducted primarily within the Chickasawhay and DeSoto Ranger Districts of the DeSoto National Forest in southern Mississippi. These two districts are disjunct from one another with their approximate geographical centers about $70 \mathrm{~km}$ apart; their nearest boundaries are approximately $27 \mathrm{~km}$ apart. The Chickasawhay is the more northerly of the two districts and encompasses portions of Jones, Wayne, and Greene counties, while the DeSoto is comprised of lands in Forrest, Perry, Stone, Pearl River, Greene, George, Harrison, and Jackson counties. Much of this area historically supported longleaf pine (Pinus palustris) savanna in uplands, habitats that were sustained by periodic fires. Lowland and mesic sites supported a diverse forest community inhabited by a variety of oaks (Quercus spp.), beech (Fagus grandifolia), magnolias (Magnolia spp.), and loblolly pine (Pinus taeda) (Frost et al. 1986). Baldcypress (Taxodium distichum) and tupelos (Nyssa spp.) occurred along streams and associated swampy areas. Suppression of natural fire regimes, along with intense harvest of trees during the early 20 th century, greatly altered the structure and composition of forests in southern Mississippi. For example, most stands of longleaf pine were replaced by faster-growing loblolly pine $(P$. taeda) (Frost et al. 1986). Restoration of the original longleaf pine community is underway within some areas of the NF, with riparian areas dominated by native hardwoods.

\section{MATERIALS AND METHODS}

To locate bridge-roosting $C$. rafinesquii, we surveyed 90 bridges within or near DeSoto NF from March through June 2000. If we found $\geq 1$ C. rafinesquii on our initial visit to a bridge, we subsequently visited that site biweekly (once every two weeks) through September 2000 and once per month from October 2000 through January 2001. We did not count presence of guano under a bridge as proof of its use by $C$. rafinesquii because we could not verify that the scat had been left by this species. We routinely checked 14 bridges in the Chickasawhay District and 14 bridges in the DeSoto District during the aforementioned interval. In February 2001 the Forest Service identified 22 bridges (including most of the 14 that we were checking) to be replaced within the Chickasawhay District, eight of which had not previously been surveyed for bats. Consequently, we checked 22 bridges in the Chickasawhay District once per month in February, March, and April, while continuing to check the bridges in the DeSoto District. We conducted biweekly surveys of bridges in both districts from May 2001 through July 2001. After a seven-month break, we resumed surveys of the bridges in the Chickasawhay District from late March through September 2002. In 
2002 we visited bridges biweekly during May through July but conducted monthly surveys outside of this interval.

We always surveyed bridges during daylight hours; surveys consisted of one or more investigators visually scanning the underside of the bridge for bats. Upon finding $C$. rafinesquii, we counted them and noted whether pups were present. To minimize disturbance to colonies we assessed development of pups by observing them (from a distance $\geq 3 \mathrm{~m}$ ) with closefocus binoculars. We identified bats as juveniles or adults based on color of pelage, with juveniles being dark gray as is characteristic of the species for the first 2-3 months of life (Jones 1977) and adults having a rich brown coat on their dorsal side (Jones and Suttkus 1975). We attempted to capture solitary $C$. rafinesquii throughout the survey; we did not disturb colonies if there were females in the act of nursing young. To catch bats we used a "butterfly" net attached to an aluminum handle of adjustable length. We determined sex, age-class (juvenile or adult), weight, and length of forearm for captured individuals. We placed an individually numbered, splitplastic ring on the right or left forearm (depending upon the sex of the bat) of most individuals that we captured. These methods followed University of Southern Mississippi IACUC protocol \# 204-004.

\section{RESULTS}

Thirty-six bridges in or near DeSoto NF were used by $C$. rafinesquii at least once during the survey. Number of bats present under an occupied bridge ranged from 1 to 25 . Combining both districts, the mean number of individuals per occupied bridge was 4.6 (SD [standard deviation] $=5.8)$ in 2000 and $3.9(\mathrm{SD}=5.0)$ in 2001. This value was 3.0 (SD $=4.4$ ) for the Chickasawhay District in 2002. The mean number of adult females per maternity colony over the duration of the study was 5.6 (SD $=3.1$ ). We identified 20 bridges as being maternity or nursery roosts; that is, we observed at least one adult female with a pup at these bridges on at least one occasion.

\section{Development of maternity colonies}

We first observed a maternity colony on 9 March 2000 and found small numbers (1-5) of females at a few bridges during that month. Upon capturing a few individuals at several bridges, one of us (AWT) palpated their noticeably swollen abdomens and determined them to be pregnant. Mean and maximum numbers of bats slowly increased through early May (Figs. 1 and 2). We first observed pups in mid-May; we saw a female nursing a naked pup on 12 May 2000 under a bridge in the Chickasawhay District (three adults without pups also were present in this colony). In the DeSoto District, we discovered pups at four sites on 18 May 2000; all of these pups were nursing. Although some of these pups were naked, others already had hair. In both districts, we found the 
largest colonies in June 2000 (Figs. 1 and 2). In the Chickasawhay District the mean number of individuals per bridge occupied by $C$. rafinesquii peaked in July 2000 with $5.4(\mathrm{SD}=5.7)$. In the DeSoto District the highest mean was $11.1(\mathrm{SD}=8.9)$ bats per bridge in June 2000. By early June pups had attained flight, but we continued to catch females with exposed nipples through 14 July.

Occupancy of bridges by bats peaked in late spring/ early summer 2000 in both districts (Figs. 1 and 2). In the Chickasawhay District $C$. rafinesquii used the highest proportion of bridges $(59 \%, 10$ of 17 checked) during June 2000. In the DeSoto District bats were most frequently encountered in May 2000 (65\%, 17 of 26). Percentage of bridges used in the Chickasawhay District declined sharply as summer progressed, stabilized in early fall, then declined to zero from November through January, before rising slowly toward a second (albeit much smaller) late-spring peak in 2001 (Fig. 1). A more gradual decline in use of bridges by $C$. rafinesquii occurred in the DeSoto District during summer and fall 2000 (Fig. 2).

In 2001 we did not observe maternity colonies until 20 April in the Chickasawhay District and 5 May in the DeSoto District. We saw the first pups of the year on 15 May and 17 May in the Chickasawhay and DeSoto Districts, respectively; the pups were naked in both cases. In

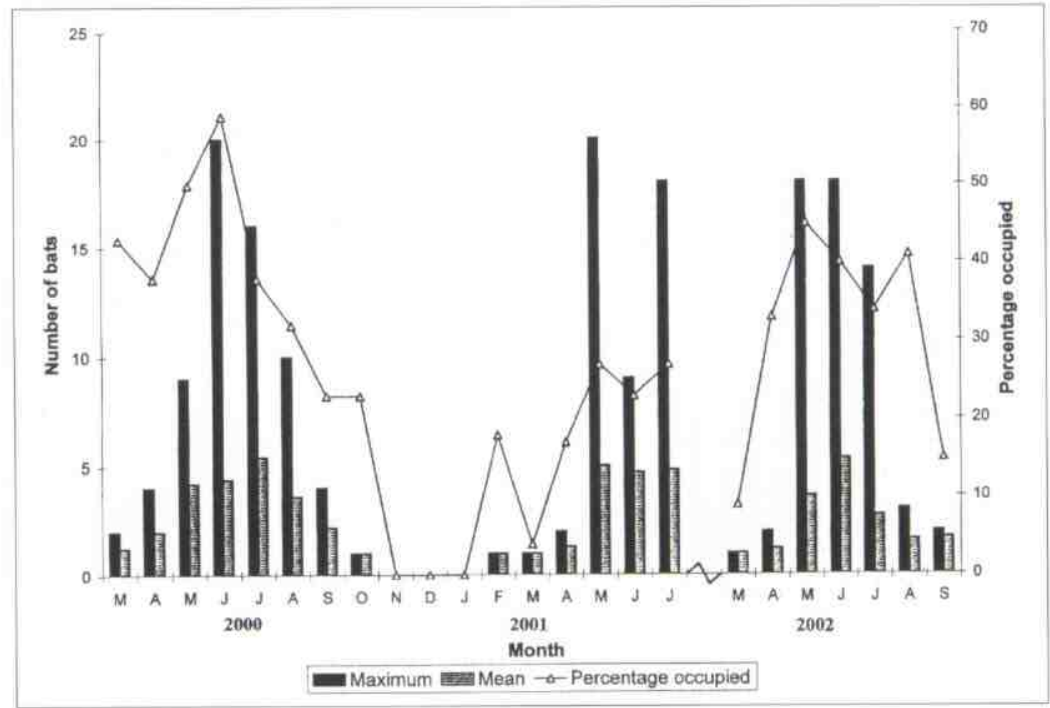

Figure 1. Relative abundance of Rafinesque's big-eared bats (Corynorhinus rafinesquii) in the Chickasawhay District, Desoto National Forest, MS, based on maximum and mean number of bats roosting under occupied bridges and percentage of bridges surveyed that were used by bats. (Data grouped by month.) Surveys conducted from March 2000 through July 2001 (no bats were found during November, December, or January) and March 2002 through September 2002. 
2001 the largest colonies in the Chickasawhay District were found in May, during which the mean number of individuals per occupied bridge was $5.0(\mathrm{SD}=6.7)$ and the maximum number of individuals was 20 . In the DeSoto District the highest mean for 2001 was found in July (6.8, $\mathrm{SD}=6.4)$. Although the proportion of bridges used by bats fluctuated during the early months of $2001,50 \%$ (13 of 26) of all bridges surveyed in the DeSoto District during July 2001 were used as roosts. In 2001 we last observed juvenile $C$. rafinesquii in the company of adult females, some of which were lactating, on 25 July.

In 2002 we found the first maternity colonies at two bridges on 15 May; frequent visits to these sites revealed that the pups were born between 23 and 27 May. The largest colonies were comprised of 18 individuals (adult females and pups) in both May and June. Bats were most commonly found under bridges in May (Fig. 1), while the highest mean number of bats per bridge $(5.3, \mathrm{SD}=6.6$ ) was found in June (Fig. 1). We captured lactating adult females as late as 16 July. The last example of maternal behavior that we observed consisted of an adult female roosting with a juvenile male on 17 August 2002.

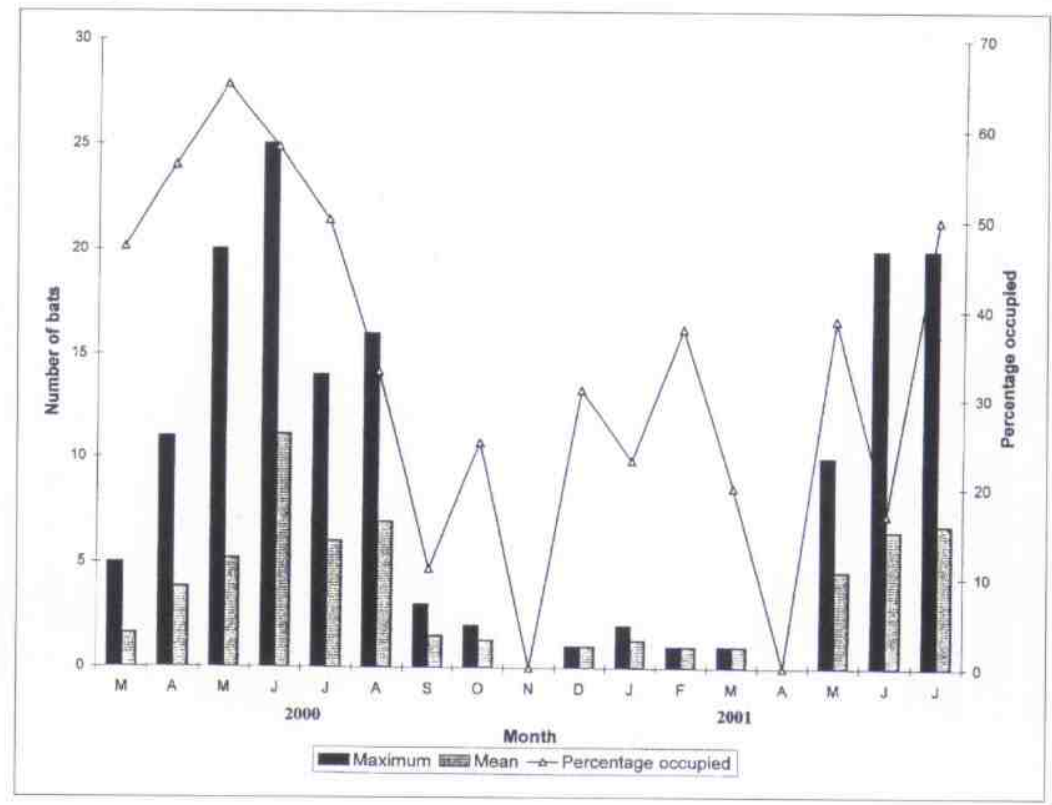

Figure 2. Relative abundance of Rafinesque's big-eared bats (Corynorhinus rafinesquii) in the DeSoto District, Desoto National Forest, MS, based on maximum and mean number of bats roosting under occupied bridges and percentage of bridges surveyed that were used by bats. (Data grouped by month.) Surveys conducted from March 2000 through July 2001 (no bats were found during November 2000 and April 2001). 


\section{Occurrences of solitary roosting}

Colonies were absent from the bridges that we checked between 26 September 2000 and 8 April 2001, and from 29 March 2002 through 2 May 2002. However, solitary $C$. rafinesquii were present under bridges throughout most of the study period. We sometimes found solitary bats in torpor on days following nights where temperatures dropped to $\leq 16$ ${ }^{\circ} \mathrm{C}$. This phenomenon was especially common in the DeSoto District, where solitary bats occupied approximately one-third of all bridges in December 2000 and nearly $40 \%$ of all bridges in February 2001 (Fig. 2).

Solitary $C$. rafinesquii that we encountered throughout the study period were typically adult males. A male found under a bridge on 9 March 2000 had enlarged testes and epididymides descended fully into the uropatagium. Enlargement of testes coincides with periods of mating in Corynorhinus (Whitaker and Hamilton 1998), which, according to Barbour and Davis (1969), extend from fall through winter in $C$. rafinesquii. We did not capture any more males displaying this condition until mid-October 2000 , but four of five males captured during that month had enlarged testes and epididymides. We located adult males roosting beside females only twice, on 28 August 2000 (one male and two females) and on 12 October 2000 (one male and one female). The few males that we found in colonies during the late spring and early to mid-summer were juveniles.

\section{DISCUSSION}

The phenological development of maternity colonies was similar among the three years of observation. We found the first colonies of the year as early as mid-March and as late as mid-May. In southern Arkansas, maternity colonies formed during March inside abandoned buildings (England et al. 1989). We consistently noted a trend toward greater abundance of $C$. rafinesquii and increased use of bridges as spring progressed. In the present study, the timing of parturition was more precise than the onset of colony formation. We found naked (newborn) pups on 12 May and 18 May in 2000, on 15 May and 17 May in 2001, and on 27 May 2002. These data are consistent with dates of parturition reported for $C$. rafinesquii by Jones and Suttkus (1975) in southwestern Mississippi and in southeastern Louisiana, but are somewhat earlier than what Clark (1990) observed in the Coastal Plain of North Carolina (early to mid-June). In mid- to late summer, we noted a decline in colony size and concomitant decrease in the proportion of bridges used in both districts in 2000 and in the Chickasawhay District in 2002 (we did not conduct surveys after July in 2001). Considering that these colonies consisted almost exclusively of adult females and their offspring, and that solitary individuals encountered during cooler months were mostly males, the lack of bats found under bridges outside of the 
maternity season was likely due to roost switching by females. Jones and Suttkus (1975) reported that male $C$. rafinesquii were more common at roosts from fall through winter and females were more common during spring and summer. Hurst and Lacki (1999) found that population size in $C$. rafinesquii over time was stable despite low juvenile mortality, suggesting that emigration (particularly by females) offset any expected gain from recruitment. Data from recaptures of $C$. rafinesquii that were banded at bridges (Trousdale and Beckett, unpubl.) corroborate Jones and Suttkus' (1975) opinion that long-term residents of roost sites tend to be males.

The relative scarcity of $C$. rafinesquii under bridges in fall and winter suggests that most of the population used other types of roosts during these seasons. England et al. (1989) reported a decline in abundance of $C$. rafinesquii roosting in abandoned houses during fall and a concomitant increase in bats found in cisterns. A colony numbering in excess of 100 individuals was observed at an abandoned school in southern Arkansas during autumn (D. Saugey and R. Sikes, pers. comm.). Although we located several abandoned buildings within the study area, use of these structures by colonies of $C$. rafinesquii was limited. On 24 September 2001 we located a colony roosting inside a dilapidated house; in subsequent visits to this site over the next 2 weeks, we found that the colony was comprised of both sexes and fluctuated in number between 2 and approximately 25 individuals. Regardless, we have not seen colonies using this building during more recent visits. Hurst and Lacki (1999) documented $C$. rafinesquii using a cave in Kentucky as a winter hibernaculum, but Best et al. (1992) recorded only a single specimen of $C$. rafinesquii during their surveys of caves in the Coastal Plain of Alabama. Although no caves are known from DeSoto NF, several limestone caves are found along the Vicksburg Group in Wayne County (Cliburn and Middleton 1983), located approximately $25 \mathrm{~km}$ from the northernmost boundary of the Chickasawhay District. We have yet to locate $C$. rafinesquii in any of these caves, despite having visited them during both warm and cool months (Trousdale and Beckett, unpubl.).

The size of colonies of $C$. rafinesquii that we observed were generally smaller than those reported by other investigators who monitored roosts used by this species. We never found more than 25 bats in a single colony; in contrast, Lance et al. (2001) observed a maximum of approximately 50 individuals under a single bridge. A maternity colony using a cave in Kentucky numbered over 100 individuals (Hurst and Lacki 1999), while Hoffmeister and Goodpaster (1963) recorded up to 64 bats from a cistern in Tennessee. The mean number of adult females per maternity colony in DeSoto NF $(5.6, \mathrm{SD}=3.1)$ was considerably smaller than that reported by England et al. (1989) from abandoned 
houses (30, SD not reported). Difference in size of colonies among roosts may reflect intensity of intraspecific competition, with smaller colonies occurring where quality or availability of foraging habitat are low (Entwistle et al. 2000). Another factor influencing colony size in our study might have been the high density of potential roosts, which allowed bats to use multiple roosts over short-term periods instead of returning to the same site each day (Trousdale and Beckett, unpubl.).

Finally, we concur with Jones and Suttkus (1975) and Belwood (1992) that $C$. rafinesquii's tendency to roost at sites susceptible to human disturbance and their fidelity to these roosts could easily imperil populations. We urge managers and engineers to consider the "window" of time in which maternity colonies of $C$. rafinesquii depend on concrete bridges as nursery roosts, so that repairs or replacement of bridges not coincide with their presence. Based on our data, this time interval extends from March through August in southern Mississippi.

\section{ACKNOWLEDGMENTS}

We thank the U.S. Forest Service and the Mississippi Museum of Natural Science for providing funding for this project. We especially thank C. Brown and D. Berens of the Forest Service for coordinating logistical assistance and for their steadfast support of our research. J. Himes, E. Wooten, R. Wells, B. Blisset, and D. Lofton assisted in collection of data. S. Loeb and two anonymous reviewers contributed suggestions that helped improve this manuscript. R. Lance, D. Miller, M. Kennedy, and C. Martin provided input over the course of our research.

\section{LITERATURE CITED}

Adam, M.D., and J.P. Hayes. 2000. Use of bridges as night roosts by bats in the Oregon Coast Range. Journal of Mammalogy 81:402-407.

Barbour, R.W., and W.H. Davis. 1969. Bats of America. University of Kentucky Press, Lexington, KY. 286 pp.

Belwood, J.J. 1992. Southeastern big-eared bat. Pp. 287-293, In S.R. Humphrey (Ed.). Rare and Endangered Biota of Florida, Vol. I (Mammals). University Press of Florida, Gainesville, FL. 392 pp.

Best, T.L., S.D. Carey, K.G. Caesar, and T.H. Henry. 1992. Distribution and abundance of bats (Mammalia: Chiroptera) in Coastal Plain caves of southern Alabama. National Speleological Society Bulletin 54:61-65.

Clark, M.K. 1990. Roosting ecology of the eastern big-eared bat, Plecotus rafinesquii, in North Carolina. Unpubl. M.S. thesis. North Carolina State University, Raleigh, NC. 112 pp.

Cliburn, J.W., and A.L. Middleton, Jr. 1983. The vertebrate fauna of Mississippi caves. National Speleological Society Bulletin 45:45-48.

Davis, R., and E.L. Cockrum. 1963. Bridges utilized as day-roosts by bats. Journal of Mammalogy 44:428-430.

England, D.R., D.A. Saugey, V.R. McDaniel, and S.M. Speight. 1989. Observations on the life history of Rafinesque's big-eared bat, Plecotus rafinesquii, in southern Arkansas. Bat Research News 30:62-63. 
Entwistle, A.C., P.A. Racey, and J.R. Speakman. 2000. Social and population structure of a gleaning bat, Plecotus auritus. Journal of Zoology, London 252:11-17.

Frost, C.C., J. Walker, and R.K. Peet. 1986. Fire-dependent savannas and prairies of the Southeast: original extent, preservation status, and management problems. Pp. 348-357, In D.L. Kulhavy and R.N. Conner (Eds.). Wilderness and Natural Areas in the Eastern United States: A Management Challenge. Center for Allied Studies, School of Forestry, Stephen F. Austin State University, Nacogdoches, TX. 416 pp.

Harvey, M.J., J.S. Altenbach, and T.L. Best. 1999. Bats of the United States. Arkansas Game and Fish Commission, Little Rock, AR. 65 pp.

Hoffmeister, D.F., and W.W. Goodpaster. 1963. Observations on a colony of big-eared bats, Plecotus rafinesquii. Transactions of the Illinois Academy of Science 55:87-89.

Hurst, T.E., and M.J. Lacki. 1999. Roost selection, population size, and habitat use by a colony of Rafinesque's big-eared bats (Corynorhinus rafinesquii). American Midland Naturalist 142:363-371.

Jones, C. 1977. Plecotus rafinesquii. Mammalian Species 69:1-4.

Jones, C., and R.D. Suttkus. 1975. Notes on the natural history of Plecotus rafinesquii. Occasional Papers of the Museum of Zoology, Louisiana State University 47:1-14.

Lance, R.F., B.T. Hardcastle, A. Talley, and P.L. Leberg. 2001. Day-roost selection by Rafinesque's big-eared bat (Corynorhinus rafinesquii) in Louisiana forests. Journal of Mammalogy 82:166-172.

Lance, R.F., and R.W. Garrett. 1997. Bat fauna of central Louisiana forests. Texas Journal of Science Supplement. 49:181-189.

Trousdale, A.W., and D.C. Beckett. 2002. Bats (Mammalia: Chiroptera) recorded from mist-net and bridge surveys in southern Mississippi. Journal of the Mississippi Academy of Sciences 47:183-188.

Whitaker, J.O., and W.J. Hamilton. 1998. Mammals of the Eastern United States. $3^{\text {rd }}$ edition. Comstock Publishing Associates, Ithaca, NY. 583 pp. 
Copyright of Southeastern Naturalist is the property of Humboldt Field Research Institute and its content may not be copied or emailed to multiple sites or posted to a listserv without the copyright holder's express written permission. However, users may print, download, or email articles for individual use. 